\title{
Constructing Regression Model for Innovative Leadership Values with Regulatory Focus Theory
}

\author{
Hakan SATIROĞLU*, Lu LIU**
}

\begin{abstract}
With the increasing attention towards innovative leadership, the inner world of leaders becomes a more interesting area than ever, especially their impact on the success of innovation. This study adopts the theory of consumption values (Sheth, Newman, \& Gross, 1991) and the Chronic Regulatory Focus theory into the innovation management to explain how leaders decide to support novel ideas and projects. The operationalisation of this theory within the perspective of leadership and innovation would not only guide organisations for investing in innovation objectively but also; this orientation would enrich the leadership literature. Therefore, this paper aims to define the leadership's values as an antecedent and formulate them within the regression model. This study and its suggested regression model can be facilitated to explain Leader's behaviour for the treasure hunter who would like to mine the gold from innovation and creativity.
\end{abstract}

Keywords: Chronic Regulatory Focus, Theory of Consumption Value (TCV), Leadership, Perception, Exploration, Replacement, Exploitation, Improvement, Innovation, Innovative Leadership.

\section{Düzenleyici Odak Kuramı ve Yenilikçi Liderlik Değerleri İçin Regresyon Modeli Olușturma}

\section{$\ddot{O} z$}

Yenilikçi liderliğe artan ilgiyle birlikte, liderlerin özellikle yeniliğin başarısı üzerindeki etkileri akademisyenlerin ilgi alanına girmiş ve liderlerin bireysel değerleri ve iç dünyaları her zamankinden daha fazla ilgi alanı haline gelmiştir. Bu çalış̧a, liderlerin yeni fikirleri ve yenilikçilik projelerini desteklemeye nasıl karar verdiğini açılamak için yenilikçilik yönetimini, Tüketim Değerleri (Sheth, Newman ve Gross, 1991) ve Kronik Uyum Odak teorilerine uyarlamıştır. Bu teorinin liderlik ve yenilikçilik perspektifinde operasyonel hale getirilmesi, organizasyonlara yenilikçiliğe objektif olarak yatırım yapmalarina rehberlik etmekle kalmayacak, aynı zamanda bu yönelim liderlik literatürünü zenginleștirecektir. Bu nedenle, bu makale liderliğin değerlerini bir öncül olarak tanımlamayı ve onları bir regresyon modeli içinde formüle etmiş̧ir. Bu çalışma, liderlerin davranışlarını açıklamayı kolaylaştırıp yenilik ve yaratıcılıktan faydalanmak isteyen hazine avcılari için bir firsat oluşturacaktir.

Anahtar Kelimeler: Kronik Uyum Odaklanması, Tüketim Değerleri Teorisi, Liderlik Perspektifi, Yenilikçi Keşifleri, Yenilikçilik, Yenilikçi Liderlik.

\footnotetext{
Özgün Araştırma Makalesi (Original Research Article)

Geliş̧/Received: 06.07.2021

Kabul/Accepted: 24.01 .2022

*Associated Lecturer at Bath Business School-Bath, England, E-mail: h.satiroglu@bathspa.ac.uk ORCID https://orcid.org/0000-0001-7483-4305

${ }^{* *}$ Dr, Senior Lecturer at Bath Business School-Bath, England, E-mail: l.liu@bathspa.ac.uk

ORCID https://orcid.org/0000-0003-3047-7208
} 


\section{Introduction}

Innovation is often accepted as essential for the firm's survival. While the holistic innovation approach accepts innovation as a process that starts with creativity and front-end innovation activities and finalises with assessing the feasibility or compatibility of this new idea, the new idea could be surfaced in three different forms are called (Eisenhardt et al., 2000) Replacement, Transformation, and Improvement. Whilst Eisenhardt et al.'s did not explain how leaders select which one of these three, the path of selection is linked to Exploration, Exploitation and Ambidexterity (Simsek et al.,2009). The complexity of choosing the correct path of innovation and making selections among innovative and creative ideas are why researchers are driven into the investigation leader's internal world and display them with the regression model at the individual level.

The literature indicated that Leaders must be fulfilled or backed up various perspectives for innovational success. However, the leadership models do not specify how leaders evaluate, for example, evaluating the benefit and cost of innovation. On the one hand, numerous studies indicated that leaders' values are associated with their effectiveness and behaviours (Kark and Van Dijk, 2007 referenced Thomas, Dickson \& Bliese, 2001). Therefore, the theory of consumption value is implemented within the current study of leadership and innovation. It is not the end of the story; the supporting and backing up innovation would be too simplistic to describe the leader's behaviour that describing the leader's decision is as complex as innovation's success. Hence, leadership innovation decision is called a risky investment.

On the other hand, Kark and Van Dijk (2007), Tuncdogan et al. (2015) and Li et al. (2015) implemented "Chronic Regulatory Focus" (Wu et al., 2008) into leadership perspectives. The Regulatory starts with an individual who (leaders in our study) "may give more attention and commitment onto and based on information and evaluation of the product (information and evaluation innovative and creative ideas in our study) if they are fit into individual's regulatory concerns." (Wang et al. 2006). The regulatory fit is a continuous comparison of knowledge or evaluation driven by comparison whether it has been fit or non-fit. This notion is more heuristic than a systematic process of knowledge (Ibid).

As innovation must be supported by organisational leaders, numerous management studies attempt to investigate Leadership feature and Replacement, Improvement, Transformation, Exploration, Exploitation and Ambidextriety on a different level (Gupta et al., 2006; Jansen et al., 2008; Lavie et al.,2010; Raisch, 2008). Of these studies to today, the antecedent of organisational exploration and exploitation with focusing on leadership styles (Li et al.,2018), creativity (Li et al.,2015) have not placed sufficient concentrate on the psychological (Tuncdogan et al.,2015) and sociological antecedents of leaders. With supplying this gap throughout the innovation literature, there are several research opportunities for academics who may not only construct several methods from SEM modelling, scale building to creating parametric socio-behavioural model but also expand the area into describing the leaders' choice behaviour.

There are two contributions to this paper. The first contribution is adapting the model of Consumption Values (Sheth, Newman, \& Gross, 1991) as antecedents of regulatory focus. Although the regulatory foci and leadership were studied by Tuncdogan et al. in 2015. The current study includes the perspective of the value in the area of innovative-leader. Moreover, Sheth et 
al.'s consumption focus study has a prolific impact on its relevant literature; it has been cited over 6,000 at only google scholar and web of science.

On many occasions, it is assertive that the failure of innovation and creativity is caused by the lack of appropriate leadership support or management's follow up. While it is being debated in leadership board as a company's lifeblood, throwing all the R\&D funds or resources into innovation, there is a huge gap that academia should initiate a stream of research about how leaders select or why they support the option innovation and creative ideas. Although we are agreed with the idea that the leadership skill and factors could be the main driver of decision about innovation, it is still necessary to take into consideration of antecedents such as 'risk', 'fail', 'ambition', 'conflict avoidance', 'prosocial/competitive' and 'learned experiences' within values theory (TCV) for describing each parameter and factors. Moreover, the leaders are the persons who are responsible for designing, changing, or re-creating the organisational habitat.

Therefore, Sheth et al.'s study title manipulated as a research question of this study. 'Why leaders support creativity and innovation what they support'.

TCV focused studies, have been postulated that according to Sheth et al.'s TCV is comprised of five values with various approaches from hedonic to utilitarian. Although TCV is used in various areas and was sourced from multidisciplinary (economics, marketing, sociology, psychology) perspectives (Ceyda, 2021), the leadership of innovation studies have insufficient interest in constructing TCV. Hence, this study accepts a link between TCV and innovative-leadership values (ILV).

The second contribution of this paper is evaluating the model parameters to demarcate ILV with leader's regulatory focus, and the selection of innovation path is manipulated among Replacement-Improvement. Therefore, we develop propositions that would make distinct the innovation paths with various ILV's. Thereby, the researchers provide a theoretical construct for future studies to expand the theory of values among different relations and new variables. After completing new findings and insights, we will discuss the current study's further contributions again.

Thus, there is a requirement for a more detailed examination of leadership values. The current study is based on the regulatory focus and TCV discussed in the literature review section.

\section{Literature Review}

\subsection{Regulatory Focus}

Wang et al. (2006) and Tuncdogan and his friends (2015) point out that the "Regulatory Concept" application is used to explain a wide range of phenomena, such as eating habits, responses to antismoking campaigns, and tendencies toward some psychological disorders. Within the management subfields, strategic management and marketing have embraced this construct; the vast majority of regulatory focus articles have been published on this subject. This construct has also been applied to the fields of finance and economics, especially because of its relevance to riskattitude and managerial perspective is to task performance (Tuncdogan et al.,2015). In the 
strategic management literature, the construct is very new, although the academic interest is strong. For example, it has been applied this construct to corporate alliances (Ibid).

The theoretical framework of a leader's regulatory foci has two edges-prevention and promotion: while prevention associates with Improvement, promotion connects with Replacement. Intuitively, while a live organism might choose or engage in behaviour that helps promote or gain (Mata, Wilke, \& Czienskowski, 2013), it must prevent or avoid from loose or treat (Figure 1). This illustration is not only based on Theoretical Framework but also similar to the concept of regulatory focus. However, the regulatory emphasis is motivated by a need that would adapt for economic survival (Friedman \& Förster, 2001), precisely the same purpose could be implemented in any field. However, on the side of the spectrum, change and promotion is a desire for exploration. On the other side stability and Prevention is existed. The prevention and promotion notions are used because of a need for survival that reflects in the form of exploration and exploitation activities (March, 1991), respectively Replacement and Improvement. The survival may require a justification that it may reflect on a different level between Hedonic and Utilitarian.

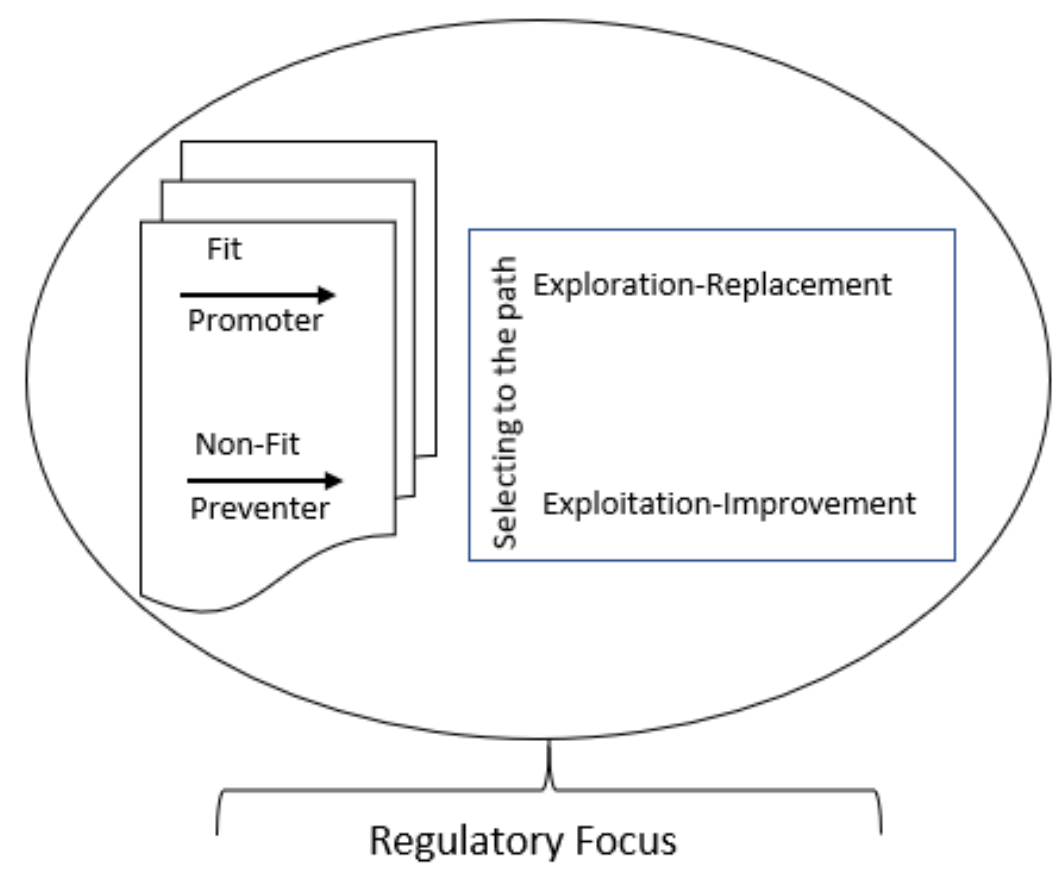

Figure 1 Promoter and Preventer at Selection Path within Regulatory Focus

\subsection{Leadership Model and Regulatory Focus}

The decision making among alternatives could be described with the theory of leader's values. Blanchard Situational Leadership Model (Hersey and Blanchard, 1969) is prominent in leadership literature; Leaders could choose one of the points between supportive behaviour and directive behaviour to implement the optimal solution (Berlyne, 1960 and 1970). While the delegating or supporting orientation may suit the employee who pledged at his skills and experiences, the coaching and directing orientation is more fitting with novice employee who is less experienced. This notion is a detailed version of 'Chronic Regulatory Focus' because the situational leader reflects her attitude corresponding to each case to survive and continue. We accepted that leaders 
choose one of the innovation paths; although they might have similar experiences previously at innovation paths, there is still a need for examination on leader's inner world and values.

Moreover, we named them the innovative leadership values in the next section. Lastly, they are expected to tackle problems according to the challenge they have confronted. Thereby, the study investigates the new approach that would be more compatible with the path of leadershipinnovation focus.

While exploitation and exploration could be applied for explaining and guessing the leaders' action (Tuncdogan, Van Den Bosch, \& Volberda, 2015; Schultz, Schreyoegg, \& von Reitzenstein, 2013) at innovation concept, furthermore, the ambidexterity is constructed on predicting partly the using of each side of exploitation and exploration as the hybrid path. The term of the path of innovation is called Exploration, Ambidexterity, and Exploitation. This trio is (Table 1) in line with Replacement, Transformation, and Improvement (Eisenhardt et al., 2000), respectively. As both Ambidexterity and Transformation are placed at the transition area, they have excluded in Table 1 and further discussion.

While exploration which could be connected with Replacement as both activities may discover novel business models, products or solutions (Tuncdogan, Van Den Bosch, \& Volberda, 2015), exploitation might have a link to the Improvement because they are more focus on strengthening regular operations or product lines without any significant change. The perpetuation of new ideas and innovation is an important deal for organisations to cope with economic and market change. Therefore, the leaders must respond to these shifts the way Replacement (exploration) and Improvement (exploitation). However, the Leaders' value proposition and the tendency to find Replacement and Improvement would be manifested in a wide range according to the individual's capacity (Griffin \& Guez, 2014). This notion is in line with supporting innovation/creativity and ultimately solve problems.

Table 1 A comparison Matrix of Two-Trios to Respond change

\begin{tabular}{|c|c|c|}
\hline & Exploitation, Exploration & Replacement, Improvement \\
\hline $\begin{array}{l}\text { Change and } \\
\text { Type Action }\end{array}$ & $\begin{array}{l}\text { Exploration pursues novel solutions } \\
\text { and change. }\end{array}$ & $\begin{array}{l}\text { Improvement; Modify the existing } \\
\text { capabilities, } \\
\text { Replacement; Acquiring or discarding } \\
\text { existing capabilities. }\end{array}$ \\
\hline $\begin{array}{l}\text { Process, } \\
\text { Duration }\end{array}$ & $\begin{array}{l}\text { Exploitation requires to search short } \\
\text { term solutions, } \\
\text { Exploration focus is on long term } \\
\text { targets. }\end{array}$ & $\begin{array}{l}\text { Improvement; Continuous incremental } \\
\text { solutions } \\
\text { Replacement is a drastic change that } \\
\text { could be because of immediate need. }\end{array}$ \\
\hline & & \\
\hline
\end{tabular}

To reiterate that the construct yet has been comprehensively linked with the "emerging of innovation" related to Replacement-Improvement literature at the individual level. This construct (Figure 3) combines the regulatory focus and Innovative-Leader Values (ILV) with a recent study frame from Tuncdogan, Van Den Bosch, \& Volberda (2015). Their multivariate regression model 
for Promotion and Prevention are suggested to explain the main driver of selection of innovation path (Ibid).

Replacement $=\mathrm{b} 0+\mathrm{b} 1 *$ Promotion $+\mathrm{b} 2 *$ Prevention + Controls $+\mathrm{e}$

Improvement $=\mathrm{g} 0+\mathrm{g} 1 *$ Promotion $+\mathrm{g} 2 *$ Prevention + Controls $+\mathrm{u}$

This model shows that Regulatory elements of the Promotion and Prevention might have partly corporate each other. Therefore, b1 $>0, b 1>b 2$ and g2>0, g2>g1. Ultimately, It does not formulate that the promotion is mutually exclusive for the Replacement, nor the Prevention is only applying for Improvement. However, the value b1 must be bigger than b2 in the case of Replacement. It is vice versa for Improvement (Tundogan et al.,2015).

\subsection{Theory of Values}

The Theory of Consumption Values is originally designed about "buy or not buy" for consumption (Sheth, Newman, \& Gross, 1991). However, the researchers implemented the innovationleadership values (ILV's), this notion about "support the innovative idea or not" from leaders' perspective. Due to a need for organisational change, leaders should consider the choice of a replacement, transformation, or Improvement. These are the paths for innovation. Moreover, there are their axiomatic suggestions are derived from Sheth's et al. as follow;

1. The value of choice is a product of the multiply values combination,

2. Accumulation of ILV's make a differential contribution in any given choice situation,

3. Five of ILV's are independent but may facilitate each other.

In order to manipulate these axiomatic suggestions within the model, the calculation of the multiply values combination could be assigned to an optimal value. This calculation is left for further studies related to the Innovative Leadership Values (ILV). ILV could be classified into five subheadings: Functional Value, Conditional Value, Social Value, Emotional Value and Epistemic Value (Figure 2).

\subsubsection{Functional Innovative Leadership Value}

The functional ILV is related to measuring the profile of choices. If leaders have a high functional perception, they are expected to focus on that particular innovation and the creative process. The leader's functional value perception is about physical performance, utilitarianism, and whether utilising cultural landscape is worth doing (Stigler, 1950) within the organisation or whether innovative ideas or creative thinking must be encouraged. However, novel ideas could be failed throughout the innovation process, such as prototyping or implementation. Thereby, throughout the alternatives, the most salient functional or utilitarian options would be appealing for leaders. Ratner and Herbest pointed out that the failure would build more cognitive and functional values (2005). For example, if the failed innovation project is similar or has a similar cue with a new path of innovation, Nelson, Malkoc and Shiv pointed out that the high functional values may boost the self-protection feelings (2018). Therefore, although they are expected to be more self-protective, which is in line with prevention foci, the leader would spend more internal resources on the Improvement activities to search for new novel ideas. Whereas their promotion foci are expected to be weaker. Hence, the regression models,

Replacement $=\mathrm{b} 0+\mathrm{b} 1_{\text {FunctionalValue }} *$ Promotion $+\mathrm{b} 22_{\text {FunctionalValue }} *$ Prevention + Controls $+\mathrm{e}$ Improvement $=\mathrm{g} 0+\mathrm{g} 1_{\text {Functionalvalue }} *$ Promotion $+\mathrm{g} 2_{\text {FunctionalValue }} *$ Prevention + Controls $+\mathrm{u}$ 
We posited that; $\mathrm{b} 1_{\text {FunctionalValueHigh }}>\mathrm{b} 1_{\text {FunctionalValueLow }}$ and $\mathrm{g} 2_{\text {FunctionalValueHigh }}<\mathrm{g} 2_{\text {FunctionalValueLow }}$

Proposition1a (1a); Functional Value moderates the relationship between a leader's Promotion focus and Replacement activities such that when high (or low) Functional Value has existed, the relationship between leader's Promotion focus and Replacement will be stronger (or weaker).

Proposition1b (1b); Functional Value moderates the relationship between leader's Prevention focus and Improvement activities such that when high (or low) Functional Value has existed, the relationship between leader's Promotion focus and Replacement will be weaker (or stronger).

\subsubsection{Social Innovative Leadership Value}

Social ILV is about the selection of social profile as an image or gaining statute. While the perception of social value is associated with socioeconomic, stereotype demographic, cultural, ethnic groups, the framework of Social Value Theory (SVT) (McClintock and Van Avermaet, 1982) represents eight different points in Figure 2. We manipulate two points of these scales, namely prosociality and competitiveness; the competitive perspective corresponds to the low social values as the focus relies on a leader's own payoff, whereas prosocial orientation could be considered a high social value in which leaders aim to increase relative payoffs for all organisational benefit.

The highly visible innovative ideas would add more symbolic, imagery or conspicuous features. Therefore, the visibility might be excess functional values due to being a member of a group or peer reputation. Thereby, Roger pointed out that the feeling of being an opinion leader would have similar to visibility (1962) that the Social ILV could boost for selecting the particular options.

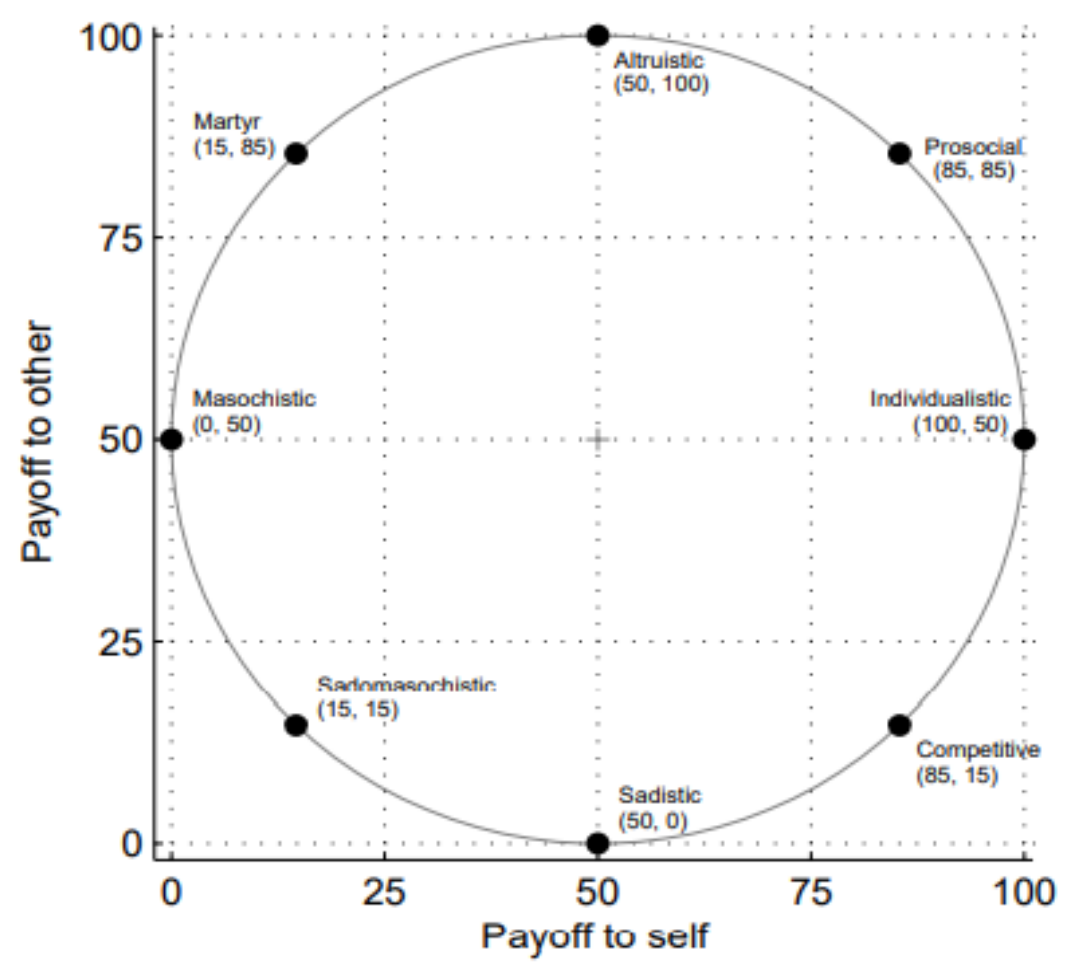

Figure 2 Social Value Framework 
In order to adjust the innovative leadership perspective, we reiterate that Replacement requires more resources and energy. In other words, the visibility of the innovation path could boost leader's prosocial orientations (high social value), whereas the less reputable path may divert leaders to choose a competitive perspective (low social values). Therefore, returning the model Replacement $=\mathrm{b} 0+\mathrm{b} 1_{\text {Socialvalue }}{ }^{*}$ Promotion $+\mathrm{b} 2_{\text {Socialvalue }}{ }^{*}$ Prevention + Controls $+\mathrm{e}$ Improvement $=\mathrm{g} 0+\mathrm{g} 1_{\text {Socialvalue }}{ }^{*}$ Promotion $+\mathrm{g} 2_{\text {Socialvalue }}{ }^{*}$ Prevention + Controls $+\mathrm{u}$ We postulate that $\mathrm{b} 1_{\text {SocialValueHigh }}>\mathrm{b} 1_{\text {SocialValue Low }}$ and $\mathrm{g} 2_{\text {SocialValueHigh }}>\mathrm{g} 2$ SocialValueLow

Propositon2a (2a); The level of Leader's Social Value moderates the relation between their promotion focus and the similar path of innovation at Replacement that when the leader has the high (or low) level of social, the association of promotion foci and Replacement will be stronger (or weaker).

Propositon2b (2b); The level of Leader's Social Value moderates the relation between their prevention focus and the similar path of innovation at Improvement that when the leader has the high (or low) level of Social, the association of promotion foci and Improvement will be stronger (or weaker).

\subsubsection{Emotional Innovative Leadership Value}

The direction of emotional values is discussed by Dichter (1947) according to noncognitive and unconscious motives that leaders' motivation would be driven by. The previous experiences would create the inclination of selecting those types of innovative alternatives. The result of the task related to the innovation can be a failure. The failure of tasks with the potential advantage of emotions over cognitive values is investigated by Nelson, Malkoc and Shiv (2018). The high emotional focus might be proof that it helps individuals to learn-Emotional Learning (Damasio, 1994). Their study confirms that the individuals who have the negative experiences of emotions are more motivated, studious, and willing to take corrective action if participants are requested to conduct similar or partly resembled tasks. This notion is parallel with Emotional Learning (Damasio, 1994). The prior failure may be caused to act for searching good choices (Ratner and Herbst, 2005). As a result, when the leader has high Emotional value after having failed at innovation path, Nelson, Malkoc and Shiv pointed out that the successful execution of the task is highly likely (2018). We manipulate the term "task" with Innovation Path of Improvement and Replacement. Hence, the high emotional values may moderate the innovation path of Improvement and Replacement. As a result of the good searching choices, these circumstances prompt leaders to engage more. Whereas the low emotional value creates opposite moderation. Hence, the regression model is;

Replacement=b0+b1 $1_{\text {Emotionalvalue }}{ }^{*}$ Promotion $+\mathrm{b} 2_{\text {EmotionalValue }}{ }^{*}$ Prevention+Controls $+\mathrm{e}$ Improvement $=\mathrm{g} 0+\mathrm{g} 1_{\text {EmotionalValue }}{ }^{*}$ Promotion $+\mathrm{g} 22_{\text {Emotionalvalue }}{ }^{*}$ Prevention + Controls $+\mathrm{u}$ We postulate that $\mathrm{b} 1_{\text {EmotionalValue High }}>\mathrm{b} 1_{\text {EmotionalValue Low }}$ and $\mathrm{g} 2$ EmotionalValue High $_{\mathrm{g}} \mathrm{g} 2$ EmotionalValue Low

Propositon3a (3a); The level of Leader's Emotional Value moderates the relation between their promotion focus and the similar path of innovation at Replacement that when the leader has the high (or low) level of emotional, the association of promotion foci and Replacement will be stronger (or weaker). 
Propositon3b (3b); The level of Leader's Emotional Value moderates the relation between their prevention focus and the similar path of innovation at Improvement that when the leader has the high (or low) level of emotional, the association of promotion foci and Improvement will be stronger (or weaker).

\subsubsection{Epistemic Innovative Leadership Value}

Curiosity, providing the novel solution and the proof of having knowledge are the centre point of epistemic values. As epistemic/knowledge is crucial for innovation, innovation's effort and spending resource is a first and foremost requirement. Locock et al.'s qualitative study about understanding the expert and opinion leader's role; they find expert knowledge is regarded as power over opinion leaders within Clinical Management (2001). Although leaders have power over subordinates, it would be considered that leaders might avoid going on discussions with experts. Unless leaders possess high knowledge or curiosity (Berlyne, 1960 and 1970) or reach or prove to have that desired knowledge, they would not promote or invest the sources. Whereas, one of the opposite notions of curiosity would be boredom which could impede learning motivation. Therefore, leaders' desire must be to learn something from their own experiences may drive their choice to support innovative initiations.

Therefore, although the less epistemic value would cause avoidance from conflict, which must cause prevention foci, thereby leader would spend more internal resources on the Improvement activities to search for new novel ideas. Whereas their promotion foci are expected to be weaker. Hence, the regression models,

We postied that; $\mathrm{b} 1_{\text {EpistemicValueHigh }}>\mathrm{b} 1_{\text {EpistemicValueLow }}$ and $\mathrm{g} 2_{\text {EpistemicValueHigh }}<\mathrm{g} 2_{\text {EpistemicValueLow }}$

Replacement $=\mathrm{b} 0+\mathrm{b} 1_{\text {EpistemicValue }}{ }^{*}$ Promotion $+\mathrm{b} 22_{\text {EpistemicValue }}{ }^{*}$ Prevention+Controls $+\mathrm{e}$

Improvement=g $0+g 1_{\text {EpistemicValue }} *$ Promotion $+g 2$ EpistemicValue $*$ Prevention + Controls $+\mathrm{u}$

Propositon4a (4a); Epistemic Value moderates the relationship between leader's Promotion focus and Replacement activities such that when high (or low) Epistemic Value has existed, the relationship between leader's Promotion focus and Replacement will be stronger (or weaker).

Propositon4b (4b); Epistemic Value moderates the relationship between leader's Prevention focus and Improvement activities such that when high (or low) Epistemic Value has existed, the relationship between leader's Promotion focus and Replacement will be weaker (or stronger). 
Hakan Satıroğlu, Lu Liu, “Constructing Regression Model for Innovative Leadership Values with Regulatory Focus Theory”, İzlek Akademik Dergi (Izlek Academical Journal), 4 (1), 2021, pp. 1-15.

Table 2 Summary of Propositions

\begin{tabular}{|c|c|}
\hline Propositions & Regression Formulations \\
\hline $\begin{array}{l}\text { Proposition1a; } \\
\text { Proposition } \mathbf{1 b} \text {; }\end{array}$ & $\begin{array}{l}\text { Replacement=b0+b1FunctionalValue*Promotion+b2FunctionalValue*Prevention+Controls }+\mathrm{e} \\
\text { Improvement }=\mathrm{g} 0+\mathrm{g} 1 \text { FunctionalValue*Promotion }+\mathrm{g} 2 \text { FunctionalValue }{ }^{\star} \text { Prevention }+ \text { Controls }+\mathrm{u} \\
\text { We postied that; } \mathrm{b} 1 \text { FunctionalValueHigh }>\mathrm{b} 1 \text { FunctionalValueLow and } \mathrm{g} 2 \text { FunctionalValueHigh }<\mathrm{g} 2 \text { FunctionalValueLow }\end{array}$ \\
\hline $\begin{array}{l}\text { Propositon2a; } \\
\text { Propositon2b; }\end{array}$ & $\begin{array}{l}\text { Replacement=b0+b1SocialValue*Promotion+b2SocialValue*Prevention+Controls }+\mathrm{e} \\
\text { Improvement }=\mathrm{g} 0+\mathrm{g} 1 \text { SocialValue }{ }^{\star} \text { Promotion }+\mathrm{g} 2 \text { SocialValue*Prevention+Controls }+\mathrm{u} \\
\text { We postulate that } \mathrm{b} 1 \text { SocialValue High> b1SocialValue Lowand g2SocialValue High }>\mathrm{g} 2 \text { SocialValue Low }\end{array}$ \\
\hline $\begin{array}{l}\text { Propositon3a; } \\
\text { Propositon3b; }\end{array}$ & $\begin{array}{l}\text { Replacement }=\mathrm{b} 0+\mathrm{b} 1 \text { EmotionalValue }{ }^{*} \text { Promotion }+\mathrm{b} 2 \text { EmotionalValue*Prevention }+ \text { Controls }+\mathrm{e} \\
\text { Improvement }=\mathrm{g} 0+\mathrm{g} 1 \mathrm{EmotionalValue}{ }^{\star} \text { Promotion }+\mathrm{g} 2 \text { EmotionalValue*Prevention }+ \text { Controls }+\mathrm{u} \\
\text { We postulate that b1EmotionalValue High }>\mathrm{b} 1 \text { EmotionalValue Lowand } g 2 \text { EmotionalValue High }>\mathrm{g} 2 \text { EmotionalValue Low }\end{array}$ \\
\hline $\begin{array}{l}\text { Propositon4a; } \\
\text { Propositon4b; }\end{array}$ & $\begin{array}{l}\text { Replacement=b0+b1EpistemicValue*Promotion+b2EpistemicValue*Prevention+Controls }+\mathrm{e} \\
\text { Improvement=g0+g1EpistemicValue*Promotion }+\mathrm{g} 2 \text { EpistemicValue }{ }^{\star} \text { Prevention+Controls }+\mathrm{u} \\
\text { We postied that; } \mathrm{b} 1 \text { EpistemicValueHigh }>\mathrm{b} 1 \text { EpistemicValueLowandg2EpistemicValueHigh }<\mathrm{g} 2 \text { EpistemicValueLow }\end{array}$ \\
\hline
\end{tabular}

\subsubsection{Conditional Innovative Leadership Value}

Among the innovation choices, the selection is depended on context or situation. The context could be a combination of the other four values. Howard and Sheth (1969) emphasise that noninternal elements would divert the choices. Attitudes or intentions could be the product of external interactions, which lead us to consider situational factors. Furthermore, the conditional values could change the priority of formerly introduced values in the inner world of leaders. For instance, the recent development of solar panel technologies impacts several sustainable investments that are now unsustainable (Trott, 2017). Therefore, this unexpected development of conditions could reprioritise a leader's values.

Moreover, the leader's aim would be not only maximising conditional values but also other four values. Any interruption of the innovation activities could be considered as a conditional value (Ceyda, 2021) which is a relevant innovative choice from a management perspective, such as the recent pandemic related interruptions. Moreover, Conditional Values can be studied as a moderator in literature (Ceyda referred from Chen et al., 2016). Therefore, while we did not introduce any regression model, the conditional values must be included in a framework with a structural equation model like Figure 2 and Figure 3. 


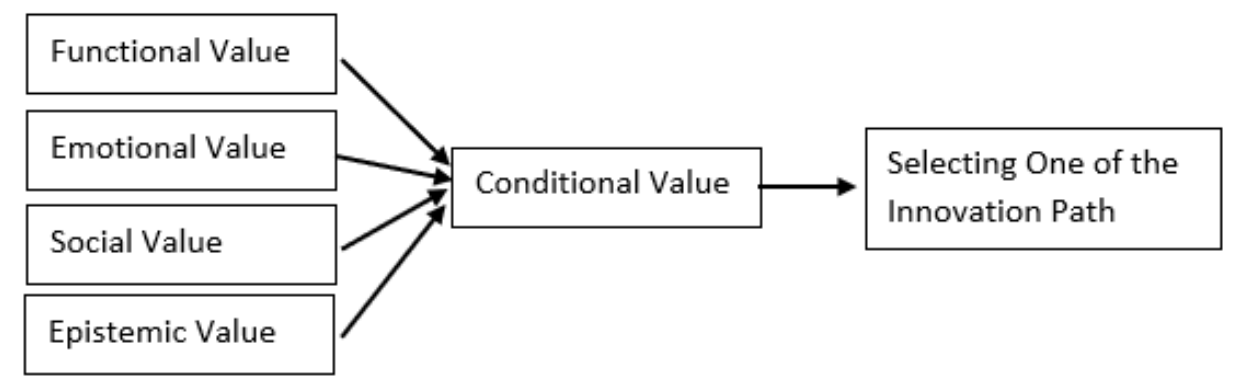

Figure 3 Prior Values of Leaders for Innovation Path

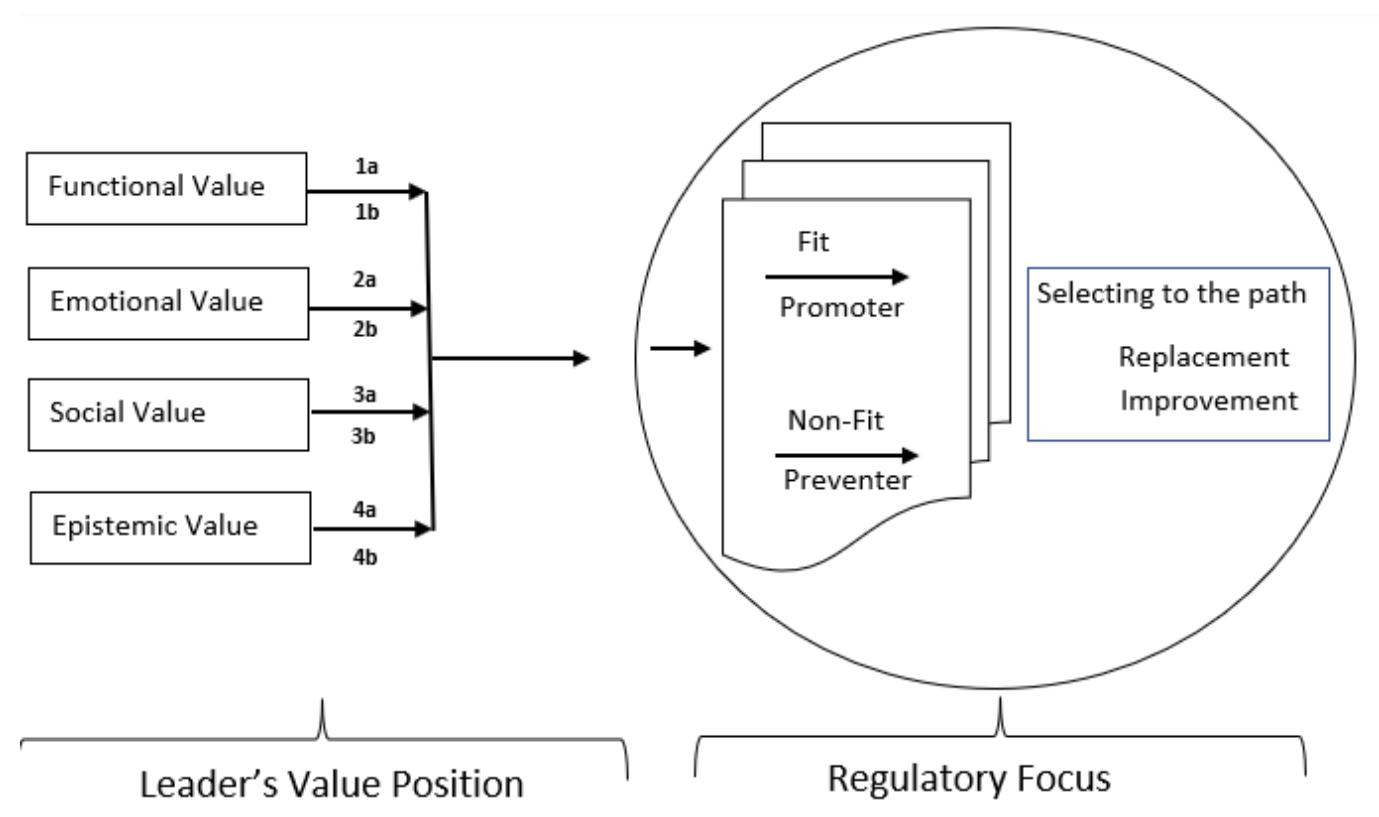

Figure 4 Integration of Propositions on framework of regulatory focus with prior values

\section{Conclusion}

This paper set five Innovative Leadership Values (ILV) within Chronic Regulatory Foci to examine the innovation paths-Replacement and Improvement. Although ILV is derived from the Value of Consumption Theory, we demonstrated a possible connection with the Regulatory Focus. Accordingly, while the paper made several contributions, it is worth mentioning some implications. Lastly, we suggest some points for future studies.

\section{Contributions and Implications}

The regulatory focus could be used as a link between Innovative Leadership and innovation paths. In order to demonstrate this link, the innovative leader's values are discussed. They may lead further investigation that the researchers could elaborate 'risk', 'fail', 'ambition', 'conflict avoidance', 'prosocial/competitive' and 'learned experiences' within ILV. The notion of elaborating for various values is given attention by other research too. For example, Marquardt et al. (2021) study three different goals orientation leaderships' within the goal orientation theory. Gershman and Niv (2015) point out that individuals could generalise previous experiences or 
knowledge. Therefore, the innovative leader's regulatory focus would take the lead this new attention. Although the paper has been reached the level of generating the regression model, the model was suitable for static notion rather than representing dynamic learning values. The model has limitation because the framework is considered as closed systems rather than addressing outside influences (Bonebright, 2010).

The leadership perspective is formulated based on the theory of value. Here, the agent presumed to act to new situation aptly-according to the situational leadership theory. However, the ecological elements were not manipulated for their possible impact on the value and decisionmaking process (Tuncdogan, Van Den Bosch, \& Volberda, 2015). Also, this paper and regression model would include the leader's characteristics and cultural and educational backgrounds.

\section{Future Directions}

The assumption and alternatives of the innovation path forward that we exclude the Transformational-Ambidexterity Innovation, as it is a hybrid way of Replacement and Improvement. So, there is a need for a further multilevel construct to examine this path. Furthermore, as a closer look into the multistage nature of innovation requires further investigation, the researchers might divide these stages and examine the ILV.

\section{References}

AHMED, P. K. (1998). Culture and climate for innovation. European journal of innovation management.

BEARDEN, W. O., \& WOODSIDE, A. G. (1977). Situational influence on consumer purchase intentions. Consumer and Industrial Buyer Behavior, 167-77.

BERLYNE, D. E., (1960). Conflict, Arousal, and Curiosity, McGraw-Hill New York.

BERLYNE, D. E., (1970). Novelty, Complexity, and Hedonic Value. Perception Psychophysics 8. 279-286.

BONEBRIGHT, D.A., (2010). 40 years of storming: a historical review of Tuckman's model of small group development. Human Resource Development International, 13(1), pp.111-120.

DAMASIO, A. R. (1994). Descartes' error: Emotion, reason, and the human brain. New York: Grosset/Putnam.

EISENHARDT, K. M., \& MARTIN, J. A. (2000). Dynamic capabilities: what are they?. Strategic management journal, 21(10-11), 1105-1121.

FRIEDMAN, R.S., \& FÖRSTER, J. (2001). The effects of promotion and prevention cues on creativity. Journal of Personality and Social Psychology, 81, 1001-1013. 
GERSHMAN, S. J., \& NIV, Y. (2015). Novelty and inductive generalisation in human reinforcement learning. Topics in Cognitive Science, 7(3), 391-415.

GOFFIN, K., \& MITCHELL, R. (2016). Innovation management: effective strategy and implementation. Macmillan International Higher Education.

GRIFFIN, A. S., GUEZ, D. (2014). Innovation and problem solving: A review of common mechanisms. Behavioural Processes, 109, 121-134.

GUPTA, A. K., SMITH, K. G., \& SHALLEY, C. E. (2006). The interplay between exploration and exploitation. Academy of management journal, 49(4), 693-706.

GURD, B., \& HELLIAR, C. (2017). Looking for leaders: 'Balancing' innovation, risk and management control systems. The British Accounting Review, 49(1), 91-102.

HERSEY, P., \& BLANCHARD, K. H. (1969). Life cycle theory of leadership. Training \& Development Journal.

JANSEN, J. J., GEORGE, G., Van den BOSCH, F. A., \& VOLBERDA, H. W. (2008). Senior team attributes and organisational ambidexterity: The moderating role of transformational leadership. Journal of Management Studies, 45(5), 982-1007.

KARK, R., \& Van DIJK, D. (2007). Motivation to lead, motivation to follow: The role of the selfregulatory focus in leadership processes. Academy of management review, 32(2), 500-528.

LAVIE, D., STETTNER, U., \& TUSHMAN, M. L. (2010). Exploration and exploitation within and across organisations. Academy of Management annals, 4(1), 109-155.

LEVINTHAL, D.A. (2011). A behavioural approach to strategy — What is the alternative? Strategic Management Journal, 32, 1517-1523.

LI, G., LIU, H., \& LUO, Y. (2018). Directive versus participative leadership: Dispositional antecedents and team consequences. Journal of Occupational and Organizational Psychology, 91(3), 645-664.

LI, L., LI, G., SHANG, Y., \& XI, Y. (2015). When does perceived leader regulatory-focused modelling lead to subordinate creativity? The moderating role of job complexity. The International Journal of Human Resource Management, 26(22), 2872-2887.

LOCOCK, L., DOPSON, S., CHAMBERS, D., \& GABBAY, J. (2001). Understanding the role of opinion leaders in improving clinical effectiveness. Social science \& medicine, 53(6), 745-757.

MARCH, J.G. (1991). Exploration and exploitation in organisational learning. Organisation Science, 2, 71-87.

MATA, R., WILKE, A., \& CZIENSKOWSKI, U. (2013). Foraging across the life span: Is there a reduction in exploration with ageing? Frontiers in Neuroscience. 
MARQUARDT, D.J., CASPER, W.J. \& KUENZI, M. (2021). Leader goal orientation and ethical leadership: a socio-cognitive approach of the impact of leader goal-oriented behavior on employee unethical behavior. Journal of Business Ethics, 172(3), pp.545-561.

MESSICK, D. M., \& MCCLINTOCK, C. G. (1968). Motivational bases of choice in experimental games. Journal of experimental social psychology, 4(1), 1-25.

McCLINTOCK, C. G., \& Van AVERMAET, E. (1982). Social values and rules of fairness: A theoretical perspective. In Cooperation and helping behaviour (pp. 43-71). Academic Press.

NELSON, N., MALKOC, S. A., \& SHIV, B. (2018). Emotions know best: The advantage of emotional versus cognitive responses to failure. Journal of Behavioral Decision Making, 31(1), 40-51.

RAISCH, S., \& BIRKINSHAW, J. (2008). Organisational ambidexterity: Antecedents, outcomes, and moderators. Journal of Management, 34(3), 375-409.

RATNER, R. K., \& HERBST, K. C. (2005). When good decisions have bad outcomes: The impact of the effect on switching behaviour. Organisational Behavior and Human Decision Processes, 96(1), 23-37.

ROGERS, E. M. (1962). Diffusion of Innovations, The Free Press of Glencoe, New York.

SCHULTZ, C., SCHREYOEGG, J., \& von REITZENSTEIN, C. (2013). The moderating role of internal and external resources on the performance effect of multitasking: Evidence from the R\&D performance of surgeons. Research Policy, 45, 1356-1365.

SHETH, J. N. (Ed.). (2011). Models of buyer behaviour: conceptual, quantitative, and empirical. Marketing Classics Press.

SHETH, J. N., NEWMAN, B. I., \& GROSS, B. L. (1991). Why we buy what we buy: A theory of consumption values. Journal of business research, 22(2), 159-170.

SIMSEK, Z., HEAVEY, C.B., VEIGA, J.F., \& SOUDER, D. (2009). A typology for aligning organisational ambidexterity's conceptualisations, antecedents, and outcomes. Journal of Management Studies, 46, 864-894.

STIGLER, G. J. (1950). The development of utility theory. Journal of political economy, 58(4), 307327.

TROTT, P. (2017). Innovation management and new product development. Pearson education.

TANRIKULU C. (2021). Theory of consumption values in consumer behaviour research: A review and future research agenda. Int Journal Consumer Study, 00:1- 22. 
TUNCDOGAN, A., Van Den BOSCH, F., \& VOLBERDA, H. (2015). Regulatory focus as a psychological micro-foundations of leaders' exploration and exploitation activities. The Leadership Quarterly, 26(5), 838-850.

WANG, J., \& LEE, A. Y. (2006). The role of regulatory focus in preference construction. Journal of Marketing research, 43(1), 28-38.

WU, C., MCMULLEN, J., NEUBERT, M., \& YI, X. (2008). The influence of leader regulatory focus on employee creativity. Journal of Business Venturing, 23, 587- 602. doi:10.1016/j.jbusvent.2007. 09.005 . 